\title{
FAKTOR-FAKTOR YANG MEMPENGARUHI KOMPETENSI PROFESIONAL GURU BIDANG KOMPETENSI KEAHLIAN TEKNIK INSTALASI TENAGA LISTRIK DI SMK
}

\author{
Saripudin \\ Politeknik TEDC Bandung \\ e- mail : bangsarip@yahoo.co.id
}

\begin{abstract}
Abstrak. Penelitian ini bertujuan untuk mengungkapkan faktor-faktor yang berpengaruh terhadap kompetensi profesional guru bidang kompetensi keahlian teknik instalasi tenaga listrik di SMK. Metode penelitan yang digunakan adalah metode survei, dengan pendekatan kuantitatif. Populasi dalam penelitian ini adalah 4 SMK Kelompok Program Studi Keahlian Teknik Ketenagalistrikan yang tersebar di Kota Bandung, Kab. Bandung Barat, dan Kab. Sumedang, sedangkan sampel penelitian adalah 2 SMKN yang memiliki Kompetensi Keahlian Teknik Instalasi Tenaga Listrik, dengan jumlah anggota sampel berjumlah 30 orang guru. Teknik pengambilan sampel ditentukan dengan menggunakan teknik cluster sampling. Pengumpulan data penelitian dengan menggunakan kuesioner dan tes. Dianalisis menggunakan analisis deskriptif, korelasi dan regresi. Hasil penelitian menemukan bahwa: (1) terdapat pengaruh yang positif dan signifikan kepemimpinan kepala sekolah terhadap kompetensi profesional guru sebesar $48 \%$, (2) terdapat pengaruh yang positif dan signifikan sikap guru tentang profesinya terhadap kompetensi profesional guru sebesar $50 \%$, (3) terdapat pengaruh yang positif dan signifikan motivasi kerja guru terhadap kompetensi profesional guru sebesar 53\%; dan (4) hasil analisis regresi ganda mengungkapkan adanya sumbangan yang positif dan signifikan kepemimpinan kepala sekolah, sikap guru terhadap profesinya, dan motivasi kerja secara bersama-sama terhadap kompetensi profesional guru sebesar $70 \%$.
\end{abstract}

Kata Kunci : kompetensi profesional guru, kepemimpinan kepala sekolah, motivasi kerja, sikap guru, kompetensi keahlian teknik intalasi tenaga listrik,

\begin{abstract}
This research aimed at revealing: the effect teacher's attitude, school principal's leadership, and teacher's working motivation on the professional of teacher competence in Electricity Program at Bandung vocational high schools. The research method used was survey with quantitative approach. The research population consists of four Electricity programs whose competence specificity in electricity installation in the city of Bandung city, West Bandung, and Sumedang regency. Based on cluster sampling technique, 30 teachers were selected as samples. The data were collected using questionnaire and analyzed using descriptive statistics, correlation technique, and multiple regression. This study reveals tha : (1) there is a positive and significant effect $(48 \%)$ of the principal's leadership on teachers' professional competence, (2) there is a positive and significant effect $(50 \%)$ of the teachers' attitude on the teachers' professional competence (3) there is an effect (53\%) of working motivation on the teachers' profesional competence, and (4) the result of multiple- regression analysis indicates that there is an effect of the teacher attitude, the principal's leadership, and teachers' working motivation on the teachers' professional competence, as much as $70 \%$.
\end{abstract}

Keywords : teacher's attitude, principal's leadership, and working motivation on the professional of teacher competence of Electricity.

\section{PENDAHULUAN}

Guru yang memiliki kompetensi profesional, menurut Peraturan Pemerintah RI No.16 tentang Standar Kualifikasi Akademik dan Kompetensi Guru, adalah guru yang melaksanakan proses pembelajaran guru dengan baik, mampu menguasai materi pelajaran secara luas dan mendalam, baik penguasaan 
materi, struktur, konsep, dan pola pikir keilmuan yang mendukung mata pelajaran yang diampu.

Kompetensi profesional guru yang terjadi saat ini sebagaimana yang dinyatakan Wardiman (1998:51), bahwa secara teoritis guru hanya akan mengajarkan apa yang dia tahu, apa yang dia bisa, dan mentransfer nilai-nilai melalui perilaku kerjanya. Guru SMK yang tidak memiliki pengalaman kerja industri, akan sulit untuk memahami wawasan mutu, wawasan pasar, wawasan keunggulan, dan wawasan nilai tambah. Bahkan sikap guru banyak dipengaruhi oleh "perilaku dan kebiasaan dosen" yang mengajar mereka, dengan ciri "kebebasan akademik" yang kurang sesuai dengan kebutuhan SMK.

Masalah lain adalah guru mengajar bidang studi tidak sesuai dengan latar belakang pendidikannya, jika ini terjadi maka akan berdampak kepada tidak optimalnya pembelajaran yang diberikan kepada siswa, sehingga terjadi mismatch (ketidaksesuaian) antara hasil pembelajaran dengan harapan pendidikan itu sendiri. Untuk itu, dalam memenuhi standar profesionalisme guru, guru harus mengajar sesuai dengan latar belakang pendidikannya. "Kalau guru berlatar belakang dari teknik listrik atau teknik sipil/bangunan, dia harus mengajar di SMK sesuai dengan jurusannya, misalkan di SMK Jurusan Listrik atau SMK Bangunan.(http://www.lampungpost.com/Januari 2009)

Guru adalah salah satu unsur dalam proses pendidikan. Guru memiliki peranan yang sangat penting dalam menentukan kuantitas dan kualitas pengajaran yang dilaksanakannya. Guru selalu memikirkan dan membuat perencanaan secara seksama dalam meningkatkan kesempatan belajar bagi siswanya dan memperbaiki kualitas mengajarnya. Uzer (2002:15) berpendapat bahwa guru profesional adalah orang yang memiliki kemampuan dan keahlian khusus dalam bidang keguruan, sehingga ia mampu melaksanakan tugas dan fungsinya sebagai guru dengan kemampuan maksimal. Tugas yang berat dari seorang guru ini pada dasarnya hanya dapat dilaksanakan oleh guru yang memiliki kompetensi profesional yang baik. Guru memegang peranan sentral dalam proses belajar mengajar, untuk itu mutu pendidikan di suatu sekolah sangat ditentukan oleh kemampuan yang dimiliki seorang guru dalam menjalankan tugasnya. 
Uzer (2002:V) mengemukakan bahwa guru sebagai pengajar atau pendidik merupakan salah satu faktor penentu keberhasilan setiap upaya pendidikan. Itulah sebabnya setiap adanya inovasi pendidikan, khususnya dalam kurikulum dan peningkatan sumber daya manusia, faktor utama selalu bermuara pada guru. Guru merupakan komponen yang berpengaruh dalam peningkatan mutu pendidikan di sekolah, sehingga kemampuan atau kompetensi profesional dari seorang guru sangat menentukan mutu pendidikan.

Kompetensi profesional guru bidang kompetensi keahlian teknik instalasi tenaga listrik di SMK meliputi: 1) penguasaan landasan kependidikan; 2) penguasaan bahan pengajaran; 3) dapat menyusun program pengajaran; 4) dapat melaksanakan program pengajaran; dan 5) dapat menilai hasil dan proses belajar mengajar yang telah dilaksanakan. Jika kelima unsur di atas dapat dilaksanakan dengan baik, maka dapat dikatakan guru profesional. Oleh sebab itu, guru profesional tidak hanya mengetahui, tetapi betul-betul melaksanakan apa-apa yang menjadi tugas dan peranannya.

Uzer (2002:6) mengemukakan bahwa guru memiliki banyak tugas, baik yang terikat oleh dinas maupun di luar dinas. Jika dikelompokan terdapat tiga jenis tugas guru, yakni;

1) tugas guru dalam bidang profesi meliputi: a) mendidik, mendidik berarti meneruskan dan mengembangkan nilai-nilai hidup. b) mengajar, mengajar berarti meneruskan dan mengembangkan ilmu pengetahuan dan teknologi. dan c) melatih, melatih berarti mengembangkan keterampilan pada siswa. 2) tugas guru dalam bidang kemanusiaan, guru menjadikan dirinya sebagai orang tua kedua bagi siswanya dan mampu menarik simpati sehingga ia menjadi idola bagi para siswanya, 3) tugas guru dalam bidang kemasyarakatan, menjadikan guru mendapatkan tempat terhormat dalam masyarakat, karena dari seorang guru diharapkan masyarakat dapat memprroleh ilmu pengetahuan.

Pendapat di atas, memberikan pengertian bahwa guru pada hakikatnya merupakan komponen strategis yang memiliki peran yang penting dalam menentukan gerak maju kehidupan bangsa. Namun kenyataan yang terjadi tidak demikian, Yamin (2008:1) mengungkapkan bahwa kalau kita lihat kehidupan guru, kehidupan mereka pas-pasan, mungkin suatu daerah disediakan perumahan dinas sederhana untuk di tempatkan menjelang mereka pensiun, begitu juga mereka mengajar di daerah terpencil dan terisolir dengan gaji yang diterima tidak 
mencukupi kebutuhan keluarganya, dan hampir tidak ada insentif atau honor di luar gaji per-bulan. Padahal dipundak mereka dipikul beban dan tanggung jawab yang besar, mencerdaskan kehidupan bangsa, merubah perilaku, dan moral anak didik. Ungkapan di atas, dapat dikatakan bahwa 1) profesi guru kurang menjamin kesejahteraan, karena rendah gajinya. Rendahnya gaji berimplikasi pada kinerjanya; 2) profesionalisme guru masih rendah, sebagaimana diungkapakan Mulyasa (2008:10), bahwa salah satu penyebab rendahnya profesionalisme guru adalah masih banyak guru yang tidak menekuni profesinya secara utuh, banyak guru yang bekerja di luar jam kerjanya untuk memenuhi kebutuhan hidup seharihari, sehingga waktu membaca dan menulis bagi peningkatan diri tidak ada, belum adanya standar profesional guru sebagaimana tuntutan negara-negara maju, serta kurangnya motivasi kerja guru dalam meningkatkan kualitas diri.

Rendahnya pengakuan sikap guru terhadap profesinya pada saat ini seperti yang diungkapkan oleh Uzer (2002:1), bahwa masih rendahnya pengakuan profesi guru dalam masyarakat, yaitu: 1) adanya pandangan sebagian masyarakat, bahwa siapapun dapat menjadi guru asalkan ia berpengetahuan, 2) kekurangan guru di daerah terpencil, memberikan peluang untuk mengangkat seseorang yang tidak mempunyai keahlian untuk menjadi guru, 3) banyak guru yang belum menghargai profesinya, dan adanya perasaan rendah diri karena menjadi guru, 4) kelemahan yang terdapat pada guru itu sendiri, diantaranya adalah rendahnya tingkat kompetensi profesionalisme guru seperti, penguasaan guru terhadap materi dan metode pengajaran masih di bawah standar, serta 5) kurangnya motivasi kerja guru dalam meningkatkan kompetensi profesionalnya.

Sikap guru terhadap profesinya merupakan keyakinan seorang guru mengenai profesi yang diembannya, dan memberikan dasar kepada guru untuk membuat respon atau perilaku sesuai dengan pilihannya.

Sikap guru terhadap profesi juga mempengaruhi tindakan guru dalam menjalankan profesinya. Jika seorang guru memiliki sikap positif terhadap profesinya, maka guru tersebut akan menjalankan fungsi dan perannya dengan baik. Demikian pula sebaliknya, jika seorang guru memiliki sikap negatif terhadap profesinya, maka guru tersebut akan menjalankan fungsi dan perannya tidak sesuai dengan tuntutan profesi yang diembannya. 
Guru yang profesional pada dasarnya memiliki motivasi intrinsik sebagai pendorong untuk mengembangkan dirinya ke arah perwujudan profesional. Anwar (2000:93), mengemukakan bahwa motivasi merupakan energi untuk membangkitkan dorongan dalam diri. Jika suatu kebutuhan tidak terpuaskan (unsatisfied need) maka timbul dorongan (drive) dan aktivitas individu untuk merespon perangsang (incentive) dalam tujuan (goal) yang diinginkan. Sebaliknya jika tujuannya tercapai, maka dia akan merasa puas (satisfied need) dengan apa yang diraihnya.

Guru yang memiliki motivasi untuk melakukan pekerjaan, menunjukkan adanya dorongan dalam dirinya untuk bekerja dengan baik. Jika seorang guru mempunyai harapan yang besar dapat berprestasi tinggi, dan jika ia menduga bahwa dengan tercapainya prestasi yang tinggi ia akan merasakan akibat-akibat yang ia harapkan, maka ia akan mempunyai motivasi yang tinggi untuk bekerja. Sebaliknya jika guru merasa yakin tidak akan dapat mencapai prestasi kerja sesuai dengan yang diharapkan pimpinan sekolah, maka ia akan kurang termotivasi untuk bekerja. Meningkatnya motivasi kerja akan menghasilkan lebih banyak usaha dan prestasi yang lebih baik.

Rendahnya motivasi kerja guru dalam mengajar akan berdampak terhadap hasil mutu pendidikan, rendahnya ini akibat dari kurang tanggapnya pihak-pihak terkait terhadap nasib guru. seperti: (1) gaji guru yang rata-rata rendah dan belum memadai, akibatnya guru mencari alternatif sumber penghasilan lain, (2) kejenuhan birokrasi mengurus pindah tugas (3) peluang kecil bagi peningkatan karir (5) rendahnya kepemimpinan kepala sekolah untuk menjadi teladan/panutan. (http://www.mentawai.org/pot9.htm, 27 Januari 2009)

Paparan di atas bukanlah merefleksikan kepesimisan dan kurangnya kredibilitas (kepercayaan) kepada guru. Kondisi di atas harus diubah, jika ingin mewujudkan kualitas pendidikan yang baik, dan sumber daya manusia yang memiliki kemampuan daya saing tinggi, maka pemerintah sebagai pengambil kebijakan pendidikan diharapkan lebih respontif terhadap aspirasi dan nasib guru dalam peningkaatan kesejahteraannya. Peningkatan kesejahteraan guru perlu diupayakan sejalan dengan peningkatan profesionalisme dan kompetensi guru. Kepala sekolah sebagai penanggung jawab penyelenggaraan pendidikan di 
sekolah diharapkan dapat meningkatkan kinerjanya, sebagai tauladan bagi guru, guru harus menjadi panutan siswa dan masyarakat di lingkungannya. Sehingga kekhawatiran terhadap rendahnya motivasi kerja guru dalam proses belajar mengajar dapat dihindari sedini mungkin.

Motivasi kerja dari uraian di atas dapat disimpulkan bahwa motivasi kerja merupakan dorongan atau kekuatan untuk melakukan suatu pekerjaan, meliputi komitmen terhadap pekerjaan, dorongan keterlibatan di dalam pekerjaan termasuk kehadiran dan penyelesaian pekerjaan, keinginan untuk meningkatkan mobilitas kerjanya, keinginan untuk maju dan berprestasi, serta ketahanan kerja seseorang dalam menghadapi hambatan kariernya.

Guru yang memiliki motivasi untuk melakukan pekerjaan, menunjukkan adanya dorongan dalam dirinya untuk bekerja dengan baik. Jika seorang guru mempunyai harapan yang besar dapat berprestasi tinggi, dan jika ia menduga bahwa dengan tercapainya prestasi yang tinggi ia akan merasakan akibat-akibat yang ia harapkan, maka ia akan mempunyai motivasi yang tinggi untuk bekerja. Sebaliknya jika guru merasa yakin tidak akan dapat mencapai prestasi kerja sesuai dengan yang diharapkan pimpinan sekolah, maka ia akan kurang motivasinya untuk bekerja. Meningkatnya motivasi kerja akan menghasilkan lebih banyak usaha dan prestasi kerja yang lebih baik. Dengan demikian motivasi kerja diduga turut berperan di dalam meningkatkan kompetensi profesional guru.

Guru dalam menjalankan tugas dan perannya tidak terlepas dari kebijakan dari pimpinan sekolah, sebuah sekolah adalah organisasi yang kompleks dan unik, sehingga memerlukan koordinasi yang baik. Oleh sebab itu kepala sekolah yang berhasil, yaitu tercapainya tujuan sekolah, serta tujuan dari para guru dan staf yang ada di dalam lingkungan sekolah. Wahjosumijo (2007:3) menyatakan bahwa kepala sekolah adalah orang yang menentukan fokus dan suasana sekolah. Keberhasilan sekolah adalah sekoloh yang memiliki pemimpin yang berhasil (effective leaders). Pemimpin sekolah adalah mereka yang dilukiskan sebagai orang yang memiliki harapan tinggi terhadap guru/staf dan para siswa, pemimpin sekolah adalah mereka yang banyak mengetahui tentang tugas-tugas mereka, dan yang menentukan suasan untuk sekolah mereka. 
Kualitas kepemimpinan kepala sekolah di dalam mencapai keberhasilan suatu sekolah, ditentukan dengan sejauhmana kepala sekolah mampu untuk memimpin. Wahjosumijo (2007:5) mengemukakan bahwa kepala sekolah sebagai pemimpin harus mampu: 1) menimbulkan kemauan yang kuat dengan penuh semangat dan percaya diri para guru dan staf dalam melaksanakan tugas masingmasing, 2) memberikan bimbingan dan mengarahkan para guru dan staf serta memberikan dorongan, memacu dan berdiri di depan demi kemajuan dan memberikan inspirasi dalam mencapai tujuan.

Seorang kepala sekolah, dari segi kepemimpinan perlu mengadopsi gaya kepemimpinan transformasional, agar semua potensi yang ada di sekolah dapat berfungsi secara optimal. Kepemimpinan transformasional dapat didefinisikan sebagai gaya kepemimpinan yang mengutamakan pemberian kesempatan, dan atau mendorong semua unsur yang ada dalam sekolah untuk bekerja atas dasar sistem nilai (values system) yang luhur, sehingga semua unsur yang ada di sekolah (guru, siswa, pegawai, orangtua siswa, masyarakat, dan sebagainya) bersedia, tanpa paksaan, berpartisipasi secara optimal dalam mencapai tujuan ideal sekolah. Beberapa fenomena pendidikan persekolahan sebagai hasil dari model kepemimpinan yang instruktif dan top down, antara lain, sistem target pencapaian kurikulum, target jumlah kelulusan, formula kelulusan siswa, dan adanya desain suatu proyek peningkatan kualitas sekolah yang harus dikaitkan dengan peningkatan nilai UN (Ujian Nasional) secara instruktif. Keadaan ini berakibat pada terbelenggunya seorang kepala sekolah dengan juklak dan juknis. Dampak negatifnya ialah tertutupnya sekolah pada proses pembaharuan dan inovasi pendidikan. (http://www.tendik.org, 27 Januari 2009).

Kepemimpinan kepala sekolah sebagai pemimpin sekolah yaitu bertanggung jawab dalam menciptakan suasana belajar mengajar yang kondusif. Pimpinan sekolah dituntut untuk dapat bekerja sama dengan guru dan staf sekolah. Sebaliknya, jika kepemimpinan kepala sekolah yang berorientasi hanya pada pengadaan sarana dan prasarana dan kurang memperhatikan kompetensi profesional guru dan karyawannya, maka dapat menyebabkan guru dapat melalaikan tugas sebagai pengajar, sehingga pada akhirnya, berimplikasi terhadap sikap negatif dari seorang guru terhadap kepemimpinannya dan berdampak pada 
ketidakcapaiannya penguasaan kompetensi profesional guru serta keberhasilan prestasi siswa di sekolah.

Peneliti tertarik untuk mengadakan penelitian lebih lanjut mengenai kompetensi profesional guru bidang kompetensi keahlian teknik instalasi tenaga listrik di SMK dan faktor-faktor yang mempengaruhinya.

\section{METODE}

Penelitian ini menggunakan pendekatan dengan metode survei, dengan pengertian bahwa metode survei tidak memerlukan kelompok kontrol, dan generalisasi yang dilakukan bisa lebih akurat bila digunakan sampel yang representatif. Bentuk penelitian ini adalah bersifat korelasi, karena penelitian berusaha menyelidiki pengaruh antara beberapa variabel penelitian yaitu variabel kepemimpinan kepala sekolah, sikap guru terhadap profesinya dan motivasi kerja terhadap kompetensi professional.

Populasi dalam penelitian ini adalah seluruh SMK Kelompok Program Studi Keahlian Teknik Ketenagalistrikan yang tersebar di Kota Bandung, Kab. Bandung Barat, dan Kab. Sumedang, sedangkan sampel penelitian adalah SMK yang memiliki Kompetensi Keahlian Teknik Instalasi Tenaga Listrik. Teknik pengambilan sampel dalam penelitian ini menggunakan teknik cluster sampling. Teknik sampling daerah ini melalui dua tahap, yaitu tahap pertama menentukan sampel daerah, dan tahap berikutnya menentukan orang-orang yang ada pada daerah tersebut. Dari jumlah SMKN Kelompok Program Studi Keahlian Teknik Ketenagalistrikan yang tersebar di Kota Bandung berjumlah 2 SMKN dari 15 SMKN, Kab. Bandung Barat 1 SMKN dari 2 SMKN, dan Kab. Sumedang berjumlah $1 \mathrm{SMKN}$ dari $3 \mathrm{SMKN}$, selanjutnya dari tiga daerah yang memiliki program Kompetensi Keahlian Teknik Instalasi Tenaga Listrik diambil sampel 2 SMKN yaitu SMKN 4 Bandung dan SMKN 6 Bandung. Berikut jumlah sampel penelitian dalam tabel 1 di bawah ini: 
Tabel 1

Jumlah Sampel Penelitian

\begin{tabular}{clcc}
\hline No. & \multicolumn{1}{c}{ Populasi } & Sampel & Jumlah Guru \\
\hline 1 & SMK N Cihampelas Kab. Bandung Barat & & \\
2 & SMKN 4 Bandung & SMKN 4 Bandung & 13 \\
3 & SMKN 1 Sumedang & SMKN 6 Bandung & 17 \\
4 & SMKN 6 Bandung & 2 SMKN & 30 \\
\hline
\end{tabular}

Penelitian ini terdapat tiga variabel bebas, yaitu, kepemimpinan kepala sekolah $\left(\mathrm{X}_{1}\right)$, sikap guru terhadap profesi $\left(\mathrm{X}_{2}\right)$, dan motivasi kerja guru $\left(\mathrm{X}_{3}\right)$ serta satu variabel terikat yaitu kompetensi profesional guru (Y).

Insrumen penelitian ini terdapat empat data yang akan dikumpulkan, yaitu data kepemimpinan kepala sekolah menggunakan angket, sikap guru terhadap profesinya menggunakan skala likert, dan motivasi kerja guru menggunakan skala motivasi, sedangkan kompetensi profesional guru menggunakan tes. Selanjutnya instrumen dan soal tes diujikan kepada para guru yang menjadi sampel penelitian yang berjumlah 30 orang.

Instrumen tentang sikap guru terhadap profesi, kepemimpinan kepala sekolah dan motivasi kerja menggunakan uji validitas instrumen non-tes karena tidak ada jawaban yang benar atau salah, tetapi bersifat positif atau negatif. Sedangkan instrumen kompetensi profesional guru menggunakan uji validitas instrumen tes. Untuk mengetahui tingkat validitas dan realibilitas instrumen, dilakukn uji nilai skala (uji normalitas sebaran), uji daya pembeda. Uji Nilai Skala (Uji Normalitas Sebaran). Pengujian ini dimaksudkan untuk memeriksa ketepatan skala dari setiap pernyataan dengan analisis sebaran frekuensi jawaban. Uji daya pembeda ini bertujuan untuk mengetahui, apakah suatu pernyataan dapat membedakan responden yang brsikap positif dan yang bersikap negatif. Untuk maksud tersebut, pernyataan-pernyataan yang telah terbukti memiliki nilai skala yang memenuhi syarat, disusun daftar responden menurut urutan besarnya skor yang diperoleh (dari yang tertinggi ke rendah). Kemudian diambil 27\% skor tertinggi dan $27 \%$ skor terendah. Kemudian dilakukan uji-t untuk setiap pernyataan dengan rumus:

$$
t=\frac{X_{H}-X_{L}}{\sqrt{\frac{\left(X_{H-X_{H}}\right)+\left(X_{L-X L}\right)}{n(n-1)}}}
$$


dengan derajat kebebasan $\mathrm{df}=2(\mathrm{n}-1)$.

Perhitungan korelasi skor pada setiap butir dengan skor total. Perhitungan indeks korelasi menggunakan rumus Koefisien korelasi product moment dari Pearson., sebagai berikut:

$$
r=\frac{N \sum X Y-\sum X \sum Y}{\sqrt{\left(N \sum X^{2}-\left(\sum X\right)^{2}\right)\left(N \sum Y^{2}-\left(\sum Y\right)^{2}\right.}}
$$

di mana:

$\mathrm{N}$ : Jumlah responden

$\mathrm{X}$ : Skor responden untuk setiap butir

Y: Skor responden untuk seluruh butir

Butir tes dapat digunakan, apabila $r_{\text {hitung }}>\mathrm{r}_{\text {tabel }}$

Uji validitas ditempuh agar kuesioner pada instrumen penelitian memiliki internal consistency yang memadai, berarti pula memiliki contruct validity yang memadai pula. Sedangkan untuk instrumen tes, tingkat kesukaran butir tes pada dasarnya adalah peluang responden atau peserta tes untuk menjawab benar pada suatu butir soal. Indeks tingkat keukaran soal dinyatakan dengan proporsi jawaban benar atau proportion correct $(P)$. Untuk menentukan indeks kesukaran soal bentuk obyektif dapat digunakan rumus (Groundlund, 1982: 102)

$$
P=\frac{R}{T} x 100
$$

di mana:

P: Indeks kesukaran soal

R: Jumlah responden yang benar jawabannya

$\mathrm{T}$ : jumlah responden yang mengikuti tes.

Kriteria indeks kesukaran soal adalah sebagai berikut:

$\mathrm{P}=0,0-40,0$ berarti soal sukar

$\mathrm{P}=41,0-70,0$ berarti soal sedang

$\mathrm{P}=71,0-100,0$ berarti soal mudah

$\mathrm{P}=0$ berarti tak seorangpun dapat menjawab soal, dan $\mathrm{P}=100$, berarti semua responden dapat menjawab benar. Dengan demikian, bila indeks mendekati nol menunjukan soal sukar dan indeks mendekati 100 menunjukan soal mudah. Uji validitas tes menggunakan rumus korelasi point biserial $\left(r_{p b i}\right)$, yaitu:

$$
r_{p b i}=\frac{\bar{X}_{p}-\bar{X}}{s^{2}} \sqrt{\frac{p}{q}}
$$

di mana: 


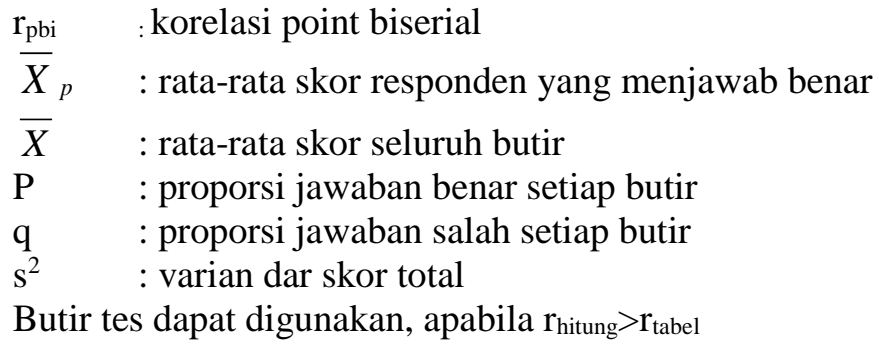

Daya pembeda butir adalah kemampuan suatu butir tes untuk membedakan antara responden tes yang mampu dengan responden yang kurang mampu atau tidak mampu. Indeks daya pembeda butir tes dapat dinyatakan dalam bentuk beda proporsi jawaban benar, koefisien korelasi biserial atau koefisien point beserial. Ketiga jenis pembeda ini menunjukan pengaruh antara suatu soal dengan total skor suatu tes. Untuk maksud uji daya beda tes bentuk obyektif, nilai responden disusun berjenjang dari nilai tertinggi sampai terendah. Kemudian diambil $27 \%$ dari nilai tertinggi dan $27 \%$ dari nilai terendah, lalu dihitung jawaban yang benar untuk setiap soal dari kedua kelompok itu.

Daya Pembeda soal dihitung dengan rumus (Groundlund, 1982: 103)

$$
D=\frac{R_{h}-R_{i}}{1 / 2 . T}
$$

di mana:

$\mathrm{R}_{\mathrm{h}} \quad$ : jumlah jawaban benar dari kelompok atas (tinggi)

$\mathrm{R}_{1} \quad$ : jumlah jawaban benar dari kelompok bawah (rendah)

$1 / 2 \mathrm{~T} \quad$ : jumlah sampel dari setiap kelompok (27\% dari jumlah seluruh sampel)

Dalam hubungan ini ditetapkan kriteria soal0soal yang memiliki daya pembeda yang baik jika $\mathrm{D}>0$. Soal-soal yang memiliki daya pembeda sama dengan nol atau negatif dibatalkan atau diperbaiki sampai memenuhi kriteria tersebut.

Uji reliabilitasnya instrumen kepemimpinan kepala sekolah, sikap terhadap profesi, dan motivasi kerja dengan menggunakan rumus Alpha Cronbach. Bila nilai butir menunjukan angka $r$ hasilnya lebih besar dari $r$ tabel sebesar 0,30, maka butir tersebut dianggap reliabel, sedangkan reliabilitasnya atau kerterandalannya didasarkan pada rumus koefisien Alpha Cronbach, sebagai berikut: 


$$
r_{1}=\left\{\frac{k}{k-1}\right\}\left\{1-\frac{\sum \sigma^{2}}{\sigma_{t}^{2}}\right\}
$$

Keterangan:

$\mathrm{r}_{1}$ : koefisien reabilitas alfa cronbach

$\mathrm{k}$ : banyaknya butir/item

$\sum \sigma_{b}^{2}:$ jumlah varian butir

$\sigma_{t}^{2}:$ varian total

Reliabilitas bentuk tes obyektif dapat digunakan rumus Kuder_Richardson-20:

$$
r_{20}=\frac{n}{n-1}\left[1-\frac{\sum p q}{s^{2}}\right]
$$

di mana:

$\mathrm{n}$ : jumlah butir tes

$\mathrm{p}$ : propors jawaban benar setiap butir

$\mathrm{q}$ : proporsi jawaban salah setiap butir

$\mathrm{s}^{2}$ : Varian dari skor total

Analisis data dilakukan melalui tiga tahapan, yaitu deskripsi data, uji persyaratan analisis, dan pengujian hipotesis. Untuk menganalisis data yang yang telah terkumpul dilakukan pengujian deskriptif dengan tahapan yaitu: a) penskoran jawaban responden, b) menjumlahkan skor total masing-masing komponen, c) mengelompokkan skor yang didapat oleh responden berdasarkan tingkat kecenderungan. Dengan menentukan banyaknya kategori menjadi empat kelompok maka sebarannya berjarak masing-masing kelompok menjadi 1,5 SB. Tingkat kecendrungan ini dijadikan sebagai kriteria.

Adapun kriterianya rerata ideal untuk 4 kategori:adalah:

$$
\begin{array}{ll}
\mathrm{Mi}+1,5 \mathrm{Sbi}<\mathrm{x} \leq \text { skor tinggi ideal } & =\text { sangat tinggi/sangat baik } \\
\mathrm{Mi}<\mathrm{x} \leq \mathrm{Mi}+1,5 \mathrm{Sbi} & =\text { tinggi/baik } \\
\mathrm{Mi}-1,5 \mathrm{Sbi}<\mathrm{x} \leq \mathrm{Mi} & =\text { cukup tinggi/cukup baik } \\
\text { Skor terendah ideal }<\mathrm{x} \leq \mathrm{Mi}-1,5 \mathrm{Sbi} & =\text { rendah/kurang baik }
\end{array}
$$

Keterangan:

$\mathrm{X}=$ skor responden

Mi = Mean ideal yang dapat dicapai oleh instrumen

Sbi = Simpangan baku ideal yang dapat dicapai oleh instrumen

Nilai Mean (ideal) dan Sbi (ideal) masing-masing ditentukan dengan cara:

$\mathrm{Mi}=0,5($ skor tertinggi ideal + skor terendah ideal $)$

Sbi $=1 / 6($ skor tertinggi ideal - skor terendah ideal $)$ 
Dengan menggunakan kriteria seperti tersebut di atas, dapat ditentukan kecenderungan data, dengan cara membandingkan nilai rerata skor dengan kriteria yang telah ditentukan.

Tahap Uji Persyaratan Analisis. Sebelum uji hipotesis, maka terlebih dahulu dilakukan uji prasyarat analisis. Adapun uji prasyarat yang dipakai dalam penelitian ini meliputi uji normalitas, uji homogenitas, dan uji linieritas. Setelah uji prasyarat terpenuhi maka langkah selanjutnya adalah pengujian hipotesis. Adapun teknik yang digunakan untuk uji hipotesis sebagai berikut: 1) Uji parsial digunakan untuk menemukan harga korelasi murni, yang tidak dipengaruhi variabel-variabel lain. Prinsipnya tiap korelasi antar variabel dapat dikontrol oleh variabel yang lain yang secara teoritis.2) Uji korelasi ganda ini digunakan untuk menguji hipotesis ke-empat variabel yaitu, kepemimpinan kepala sekolah $\left(\mathrm{X}_{1}\right)$, sikap guru terhadap profesi $\left(\mathrm{X}_{2}\right)$ dan motivasi kerja guru $\left(\mathrm{X}_{3}\right)$ serta satu variabel terikat yaitu kompetensi profesional guru (Y). Ketiga variabel bebas $\left(\mathrm{X}_{1}, \mathrm{X}_{2}\right.$ dan $\mathrm{X}_{3}$ ) dihubungkan dengan variabel terikat $(\mathrm{Y})$ dengan pola pengaruh: (1) Pengaruh variabel $\mathrm{X}_{1}$ terhadap variabel $\mathrm{Y}$, (2) Pengaruh variabel $\mathrm{X}_{2}$ terhadap variabel $\mathrm{Y}$, dan (3) Pengaruh variabel $X_{3}$ terhadap variabel $Y$ serta (4) Pengaruh variabel $X_{1}$, $\mathrm{X}_{2}$ dan $\mathrm{X}_{3}$ secara bersama-sama terhadap variabel $\mathrm{Y}$.

\section{HASIL DAN PEMBAHASAN}

1. Deskripsi Data Variabel Kompetensi Profesional Guru. Temuan penelitian berdasarkan deskrisi data yang telah disajikan, dapat diketahui bahwa kompetensi profesional guru pada kategori sangat baik sebanyak $86,67 \%$, dan kategori baik sebanyak 13,36\%, sehingga dapat disimpulkan bahwa kompetensi profesional guru secara umum dapat dikatakan sangat baik. Temuan ini memberikan informasi bahwa sebagian besar kompetensi profesional guru dalam penguasaan bidang kompetensi keahlian teknik instalasi tenaga listrik terhadap penguasaan materi pelajaran meliputi: peraturan instalasi listrik, teknik penerangan listrik, pengawatan dan pegkabelan, dan instalasi perpipaan dan saluran dikategorikan sangat baik. 


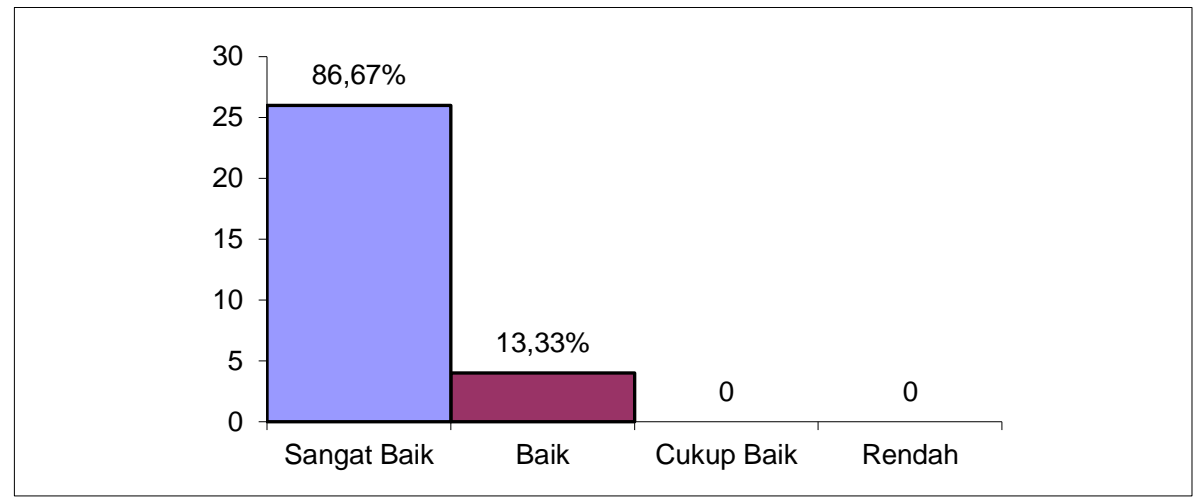

Gambar 1. Histogram Variabel Kompetensi Profesional Guru

\section{Deskripsi Data Variabel Kepemimpinan Kepala Sekolah}

Hasil temuan penelitian pada variabel kepemimpinan kepala sekolah menunjukkan bahwa kepemimpinan kepala sekolah 73,33\% pada kategori baik dan 26,67\% termasuk dalam kategori sangat baik. Dengan demkian temuan di atas, dapat dikatakan bahwa kepemimpinan kepala sekolah secara umum dapat dikatakan baik. Hasil ini menunjukkan bahwa kepemimpinan kepala sekolah, yang meliputi: kewibawaan kepala sekolah, keterampilan kepala sekolah, dan perilaku kepala sekolah sebagian besar baik. Artinya, bahwa kepala sekolah sebagai pemimpin di sekolah dengan kewibawaannya, keterampilannya dan perilakunya perlu didorong untuk dapat meningkatkan kompetensi profesional guru. Namun demikian, dari temuan ini juga dapat diketahui bahwa kepemimpinan kepala sekolah sebagian kecil memiliki kategori sangat baik, kondisi ini menunjukkan bahwa adanya pengaruh kepemimpinan kepala sekolah yang meliputi kewibawaan, keterampilan, dan perilaku kepala sekolah dalam upaya peningkatan kompetensi profesional guru.

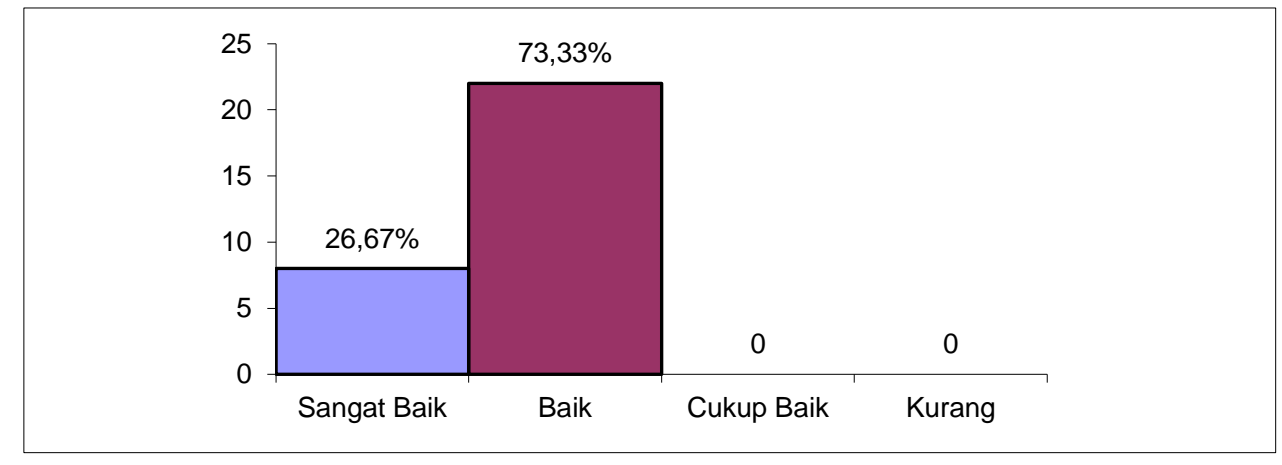

Gambar 2. Histogram Variabel Kepemimpinan Kepala Sekolah 


\section{Deskripsi Data Variabel Sikap Guru terhadap Profesinya}

Temuan penelitian mengenai sikap guru terhadap profesinya, yang meliputi: kepercayaan terhadap profesi, seperti: kesesuaian pekerjaan dengan kemampuan, dan kesesuaian dengan minat, kepuasan guru terhadap profesi yang meliputi: kepuasan guru terhadap profesinya, kepuasaan guru terhadapa gaji, peluang promosi, dan lingkungan kerja, dan perilaku guru terhadap profesinya yang meliputi: tanggung jawab, etos kerja, disiplin, dan kreativitas, didapatkan $66,67 \%$ sikap guru terhadap profesinya menunjukkan kecenderungan positif, dan 33,33\% sikap guru terhadap profesinya memiliki kecenderungan negatif. Sehingga, temuan di atas dapat disimpulkan bahwa sikap guru terhadap profesinya secara umum dapat dikatakan memiliki kecenderungan positif. Temuan di atas juga terdapat sebagian kecil guru memiliki sikap terhadap profesi keguruannya dengan kecenderungan negatif, keadaan ini menunjukkan bahwa adanya kecenderungan negatif mengganggap bahwa sikap guru terhadap profesinya baik kepercayaan guru terhadap profesinya, kepuasaan guru maupun perilaku guru terhadap profesinya dapat memberikan pengaruh terhadap kompetensi profesional guru.

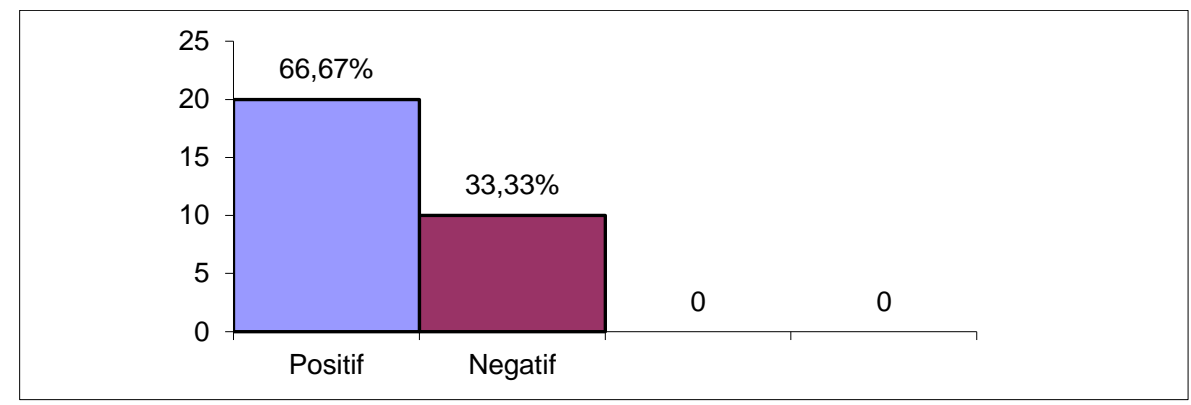

Gambar 3. Histogram Variabel Sikap Guru terhadap Profesinya

\section{Deskripsi Data Variabel Motivasi Kerja Guru}

Hasil penelitian yang diperoleh mengenai motivasi kerja guru menunjukkan bahwa motivasi kerja guru pada kategori tinggi sebanyak 43,3\%, dan kategori sedang sebanyak 56,7\%, Temuan di atas, dapat disimpulkan bahwa motivasi kerja guru secara umum dapat dikatakan sedang. Temuan ini memberikan informasi bahwa motivasi kerja guru, terkait dengan keberhasilan 
diri, pengambilan resiko, dan sifat ketergantungan guru, sebagian besar dikategorikan sedang dalam peningkatan kompetensi profesional guru.

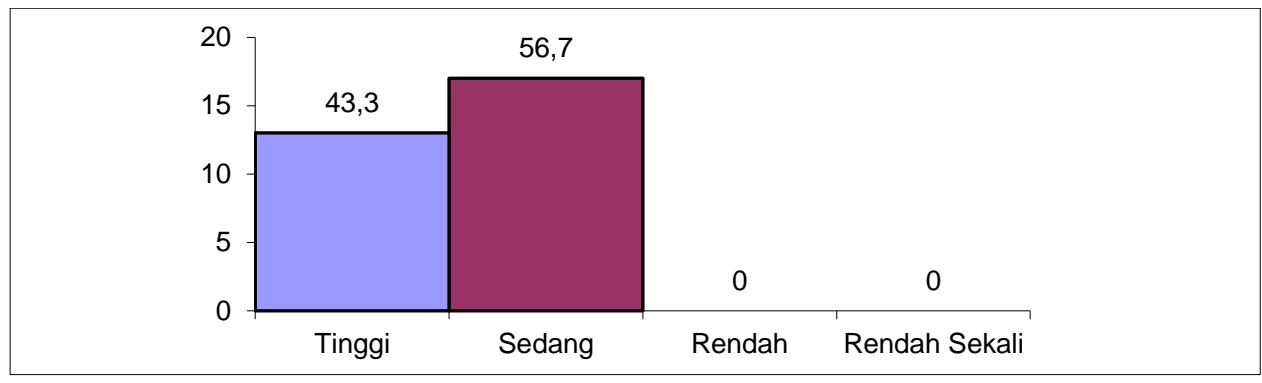

Gambar 4. Histogram Variabel Motivasi Kerja Guru

\section{Pengujian Persyaratan Analisis}

a. Uji Normalitas Uji normalitas distribusi frekuensi dari variabel $\mathrm{X}_{1}, \mathrm{X}_{2}$, $\mathrm{X}_{3}$, dan $\mathrm{Y}$ dilakukan dengan uji Liliefors (Sudjana. 1984:450). Adapun syarat kreteria uji suatu distribusi skor dikatakan normal apabila $L_{0}$ yang diperoleh dari data pengamatan lebih kecil dari pada $\mathrm{L}_{\text {tabel. }}$ Sehingga dari hasil perhitungan uji normalitas distribusi terhadap semua data dari masing-masing variabel pada taraf signifikan $\alpha=0,05$, diperoleh hasil sebagai berikut:

Tabel 2. Hasil Uji Normalitas Data Variabel $X_{1}, X_{2}, X_{3}$, dan $Y$

\begin{tabular}{lccc}
\hline \multicolumn{1}{c}{ Variabel } & $\mathrm{L}_{\mathrm{o}}$ & $\mathrm{L}_{\text {tabel }}$ & Kesimpulan \\
\hline $\mathrm{X}_{1}$ (Kepemimpinan Kepala Sekolah) & 0,087 & 0,159 & Normal \\
$\mathrm{X}_{2}$ (Sikap Guru terhadap Profesinya) & 0,118 & 0,159 & Normal \\
$\mathrm{X}_{3}$ (Motivasi Kerja Guru) & 0,138 & 0,159 & Normal \\
$\mathrm{Y}$ (Kompetensi Profesional guru) & 0,158 & 0,159 & Normal \\
\hline
\end{tabular}

Tabel 2 di atas, dapat disimpulkan bahwa distribusi data variabel $\mathrm{X}_{1}, \mathrm{X}_{2}, \mathrm{X}_{3}$, dan $\mathrm{Y}$ berdistribusi normal, sehingga memenuhi persyaratan pengujian regresi dan korelasi.

b. Uji Homogenitas. Uji homogenitas dilakukan dengan menggunakan uji Barleth. Adapun kriterian uji Barleth adalah apabila $X_{\text {hitung }}^{2}<X_{\text {tabel }}^{2}$, maka data mempunyai varian yang homogen atau berasal dari populasi yang homogen. Hasil perhitungan uji homogenitas dari data masingmasing variabel pada taraf signifikan $\alpha=0,05$ diperoleh hasil seperti di bawah ini. 
Tabel 3. Hasil Uji Homogenitas Data Variabel $X_{1}, X_{2}, X_{3}$, dan $Y$

\begin{tabular}{llll}
\hline \multicolumn{1}{c}{ Variabel } & $X_{\text {hitung }}^{2}$ & $X_{\text {tabel }}^{2}$ & Kesimpulan \\
\hline X $_{1}$ (Kepemimpinan Kepala Sekolah) & 12,21 & 42,56 & Homogen \\
X $_{2}$ (Sikap Guru terhadap Profesinya) & 14,99 & 42,56 & Homogen \\
X $_{3}$ (Motivasi Kerja Guru) & 14,42 & 42,56 & Homogen \\
Y (Kompetensi Profesional guru) & 14,99 & 42,56 & Homogen
\end{tabular}

Berdasarkan tabel 3 di atas, dapat disimpulkan bahwa data pada variabel $\mathrm{X}_{1}, \mathrm{X}_{2}, \mathrm{X}_{3}$, dan $\mathrm{Y}$. mempunyai varians yang homogen $\left(X_{\text {hitung }}^{2}<\right.$ $X_{\text {tabel }}^{2}$ ) atau berasal dari populasi yang homogen, sehingga memunuhi persyaratan pengujian selanjutnya.

\section{Pengujian Hipotesis}

a. Hasil pengujian hipotesis pertama, menunjukkan bahwa terdapat pengaruh yang positif dan signifikan kepemimpinan kepala sekolah terhadap kompetensi profesional guru. Hasil pengujian hipotesis pertama menunjukkan bahwa besar pengaruh antara kepemimpinan kepala sekolah dengan kompetensi profesional guru berdasarkan hasil perhitungan regresi, persamaan regresi linear $\hat{Y}=11,2+0,2 X_{1}$. Persamaan ini menunjukkan bahwa setiap penambahan satu unit nilai kepemimpinan kepala sekolah $\left(\mathrm{X}_{1}\right)$ akan diikuti oleh peningkatan 0,2 unit nilai kompetensi profesional guru. Koefisien korelasi pada hipotesis ini diperoleh sebesar 0,69 sehingga koefisien determinasinya adalah $48 \%$, artinya bahwa $48 \%$ variasi nilai kompetensi profesional guru ditentukan oleh faktor kepemimpinan kepala sekolah. Variasi kompetensi profesional guru sebanyak 52\% ditentukan oleh faktor-faktor lain, selain kepemimpinan kepala sekolah. Faktor-faktor lain diduga seperti: faktor gaya kepemimpinan kepala sekolah, karena seorang kepala sekolah dengan gaya kepemimpannya dapat melakukan berbagai cara dalam mempengaruhi dan memotivasi guru dan karyawannya di sekolah agar dapat berprilaku yang selalu terarah pada pencapaian tujuan sekolah. Gaya kepemimpinan kepala sekolah yang lazim disebut perilaku kepemimpinan kepala sekolah meliputi: perilaku direktif, konsultatif, partisifatif dan delegatif, faktor pengalaman kepala sekolah. Kepala sekolah yang berhasil adalah kepala sekolah yang dapat 
memerankan fungsi dan tugasnya dengan sebaik mungkin. Kepala sekolah sebagai pemimpin sekolah memiliki tanggung jawab tentang pembinaan terhadap program pengajaran, sumber daya manusia, sumber daya material dan pembinaan terhadap hubungan kerjasama antara sekolah dan masyarakat. Dalam Proses pembinaan tersebut, kewibawaan kepemimpinan kepala sekolah harus mampu menggerakkan seluruh peranan kepala sekolah baik sebagai pejabat formal, manajer, pendidik dan sebagai staf sekolah. Oleh sebab itu, jabatan kepala sekolah selalu didukung oleh kemampuan dasar manajerial, sifat, watak, pengetahuan dan keterampilan profesional, pelatihan dan pengalaman, specialized skills, karakter pribadi dan kualitas latar belakang.

b. Hasil pengujian hipotesis kedua, berdasarkan hasil pengujian menunjukan bahwa terdapat pengaruh yang positif dan signifikan sikap guru tentang profesinya terhadap kompetensi profesional guru. Hasil pengujian hipotesis kedua menunjukkan bahwa besar pengaruh sikap guru terhadap profesinya terhadap kompetensi profesional guru berdasarkan hasil perhitungan regresi diperoleh persamaan regresi linear $\hat{Y}=12,8+0,2 X_{2}$. Persamaan ini menunjukkan bahwa setiap penambahan satu unit nilai sikap guru terhadap profesinya $\left(\mathrm{X}_{2}\right)$, akan diikuti oleh peningkatan 0,2 unit nilai kompetensi profesional guru. Koefisien korelasi pada hipotesis ini diperoleh sebesar 0,71, sehingga koefisien determinasinya adalah $50 \%$, artinya bahwa $50 \%$ variasi nilai kompetensi profesional guru ditentukan oleh faktor sikap guru terhadap profesinya, meliputi: kepercayaan guru terhadap profesinya, seperti: kesesuaian pekerjaan dengan kemampuan, dan kesesuaian pekerjaan dengan minat, kepuasan guru terhadap profesi yang meliputi: kepuasan guru terhadap profesinya, kepuasaan guru terhadapa gaji, peluang promosi, dan lingkungan kerja, dan perilaku guru terhadap profesinya yang meliputi: tanggung jawab, etos kerja, disiplin, dan kreativitas, menunjukkan bahwa, sebagian besar sikap guru terhadap profesinya dikategorikan sangat baik. Sisanya, $50 \%$ variasi nilai kompetensi profesional guru ditentukan oleh faktor-faktor lain. Faktor-faktor lain, diduga seperti: faktor profesi guru 
merupakan panggilan jiwa/idealism, adanya faktor jaminan perlindungan hukum dalam pelaksanaan keprofesiannya sebagai guru, keterlibatan guru dalam organisasi-organisasi keprofesiannya (PGRI, ISPI, dll), dan adanya keyakinan seorang guru dengan keterampilan yang dimilikiya. Guru merupakan jabatan atau profesi yang memerlukan keahlian khusus sebagai guru. Profesi guru tidak bbisa dilakukan oleh orang yang tidak memilikikeahlian untuk melakukan kegiatan atau pekerjaan sebagai guru. Sehingga untuk menjadi profesi guru diperlukan syarat-syarat sebagai guru, apalagi guru profesional yang senantiasa menguasai bidang pendidikan dan pengajaran dengan berbagai ilmu pengetahuan lainnya yang perlu dibina dan dikembangkan melalui masa pendidikan tertentu.

Tugas guru sebagai profesi memiliki tugas meliputi: mendidik, mengajar, dan melatih. Mendidik berarti meneruskan dan mengembangkan nilai-nilai hidup. Mengajar berarti meneruskan dan mengembangkan ilmu pengetahuan dan teknologi. Melatih berarti mengembangkan keterampilan-keterampilan yang haru dimiliki oleh siswa.

c. Hasil pengujian hipotesis ketiga, Persamaan regresi pada hipotesis ketiga, berdasarkan hasil pengujian menunjukan bahwa terdapat pengaruh yang positif dan signifikan motivasi kerja guru terhadap kompetensi profesional guru. Hasil pengujian hipotesis ketiga menunjukkan bahwa besar pengaruh motivasi kerja guru terhadap kompetensi profesional guru berdasarkan hasil perhitungan persamaan regresi linear diperoleh $\hat{Y}=12,6+0.2 X_{3}$. Persamaan ini menunjukkan bahwa setiap penambahan satu unit nilai motivasi kerja $\left(\mathrm{X}_{3}\right)$, akan diikuti oleh peningkatan 0,2 unit nilai kompetensi profesional guru. Koefisien korelasi pada hipotesis ini diperoleh sebesar 0,73, sehingga koefisien determinasinya adalah 53\%, artinya 53\% variasi nilai kompetensi profesional guru ditentukan oleh faktor motivasi kerja guru, meliputi: dimensi keberhasilan diri, dimensi pengambilan resiko serta dimensi ketergantungan. Dimensi keberhasilan diri mencakup; pengendalian diri; kemampuan beradaptasi; kemampuan berinisiatif; mempunyai kemampuan untuk berkreativitas; memiliki standar kerja pribadi serta memiliki orientasi dalam mengembangkan diri. 
Dimensi pengambilan resiko termasuk di dalamnya kecenderungan seseorang dalam pengambilan resiko, ketakutan dalam menghadapi kegagalan serta jaminan kebutuhan dan toleransi terhadap ketidakpastian. Dimensi ketergantungan adalah kebutuhan akan persetujuan atasan serta teman seangkatan serta kebutuhan akan daya saing atau kompetisi. Sisanya, $47 \%$ nilai variasi kompetensi profesional guru ditentukan oleh faktor selain motivasi kerja guru. Faktor-faktor lain diduga seperti kepuasan kerja, keamanan kerja, adanya tujuan organisasi yang jelas, artinya adanya kepastian hukum bagi guru untuk dapat melakukan profesinya dalam proses belajar mengajar. Di samping itu diduga dipengaruhi pula oleh fasilitas yang dapat diterima guru dalam kelangsungan aktivitas guru di sekolah, baik fasilitas dalam proses belajar mengajar maupun fasilitas yang dapat dimiliki guru dalam konteks kesejahteraan, seperti kemudahan bantuan finansial, bantuan pengadaan transportasi, perumahan, dan berbagai kebutuhan lain untuk kelancaran tugasnya sebagai guru. Guru yang memiliki motivasi kerja berusaha untuk melakukan pekerjaan, menunjukkan adanya dorongan dalam dirinya untuk bekerja dengan baik. Jika seorang guru mempunyai harapan yang besar dapat berprestasi tinggi, dan jika ia menduga bahwa dengan tercapainya prestasi yang tinggi ia akan merasakan akibat-akibat yang ia harapkan, maka ia akan mempunyai motivasi yang tinggi untuk bekerja. Sebaliknya jika guru merasa yakin tidak akan dapat mencapai prestasi kerja sesuai dengan yang diharapkan pimpinan sekolah, maka ia akan kurang motivasinya untuk bekerja. Meningkatnya motivasi kerja akan menghasilkan lebih banyak usaha dan prestasi kerja yang lebih baik. Dengan demikian motivasi kerja turut berperan di dalam meningkatkan kompetensi profesional guru.

d. Hasil pengujian hipotesis keempat, menunjukkan bahwa terdapat pengaruh yang positif dan signifikan secara bersama-sama antara kepemimpinan kepala sekolah, sikap guru terhadap profesinya, dan motivasi kerja terhadap kompetensi profesional guru. Persamaan regresi pada hipotesis keempat, berdasarkan hasil persamaan regresi diperoleh 
$\hat{\mathrm{Y}}=6,1+0.1 \mathrm{X}_{1}+0,1 \mathrm{X}_{2}+0.1 \mathrm{X}_{3}$. Persamaan ini menunjukkan bahwa setiap penambahan satu unit nilai kepemimpinan kepala sekolah $\left(\mathrm{X}_{1}\right)$ akan diikuti oleh peningkatan 0,1 unit nilai kompetensi profesional guru, dan penambahan satu unit sikap guru terhadap profesinya $\left(\mathrm{X}_{2}\right)$, akan diikuti oleh peningkatan 0,1 unit nilai kompetensi profesional guru. Begitu pula dengan penambahan satu unit motivasi kerja $\left(\mathrm{X}_{3}\right)$, maka akan diikuti oleh peningkatan 0,1 unit nilai kompetensi profesional guru. Hasil analisis regresi ganda yang diperoleh melalui perhitungan SPSS, didapat koefisien determinasi (lihat pada tabel 4.14) sebesar 70\%, artinya 70\% variasi nilai kompetensi profesional guru ditentukan secara bersama-sama oleh kepemimpinan kepala sekolah, sikap guru terhadap profesinya, dan motivasi kerja guru. Sisanya, 30\% variasi nilai kompetensi profesional guru dijelaskan oleh faktor-faktor penyebab yang lain. Faktor-faktor lain tersebut dapat diduga seperti: faktor guru dalam pengelolaan program belajar mengajar, pengelolaan kelas, pengelolaan interaksi belajar mengajar, penilaian proses belajar mengajar, guru dalam proses belajar mengajar dapat menerapkan landasan kependidikan baik filosofi, psikologis, dan sosiologis, guru mampu menerapkan teori belajar sesuai dengan tarap perkembangan siswa, guru mengerti dan dapat menerapkan metode pembelajaran yang bervariasi, latar belakang pedidikan guru sesuai dengan mata pelajaran yang diampu. Di samping itu, dapat pula faktor lain diduga dipengaruhi oleh pengembangan potensi guru, baik pengembangan diri dan keprofesiannya sebagai guru. Guru sebagai pendidik ataupun sebagai pengajar merupakan faktor penentu keberhasilan pendidikan di sekolah. Tugas guru yang utama adalah memberikan pengetahuan (cognitive), sikap/nilai (affective), dan keterampilan (psychomotor) kepada anak didik, sehingga guru agar berhasil dalam pencapaian tugas dan perannya maka seorang guru harus memiliki pengetahuan tentang belajar dan tingkah laku manusia, memiliki sikap yang tepat tentang diri sendiri, sekolah, teman sejawat, dan bidang studi yang dibinanya, dan memiliki keterampilan teknik mengajar. 


\section{KESIMPULAN}

Kesimpulan penelitian ini dirumuskan berdasarkan pembahasan hasil penelitian, maka penelitian ini dapat disimpulkan sebagai berikut:

Pertama. terdapat pengaruh yang positif dan signifikan kepemimpinan kepala sekolah terhadap kompetensi profesional guru Kepemimpinan kepala sekolah, yang meliputi: kewibawaan kepala sekolah, keterampilan kepala sekolah, dan perilaku kepala sekolah sebagian besar dapat dikategorikan baik.

Kedua. terdapat pengaruh yang positif dan signifikan sikap guru tentang profesinya terhadap kompetensi profesional guru. Sikap guru terhadap profesinya yang meliputi: kepercayaan terhadap profesi, kepuasan guru terhadap profesi, dan perilaku guru terhadap profesinya, memiliki kecenderungan positif.

Ketiga. terdapat pengaruh yang positif dan signifikan motivasi kerja guru terhadap kompetensi profesional guru. Motivasi kerja guru yang meliputi keberhasilan diri, pengambilan resiko, dan ketergantungan guru, sebagian besar dikategorikan sedang.

Keempat. Terdapat pengaruh yang positif dan signifikan kepemimpinan kepala sekolah, sikap guru terhadap profesinya, dan motivasi kerja guru secara bersamasama terhadap kompetensi profesional guru.

\section{DAFTAR PUSTAKA}

Anwar. (2000). Manajemen sumber daya manusia perusahaan. PT Remaja Rosdakarya. Bandung

Gronlund, N.E. (1982). Measurement and evaluation in teaching (5th Ed). New York : Macmillan Publishng co. Inc.

Mulayasa, E. (2008). Standar kompetensi dan sertifikasi guru. Bandung: PT. Remaja Rosdakarya

Uzer Usman. (2002). Menjadi guru profesional. Bandung: Remaja Rosda Karya

Wahjosumidjo. (2002). Kepemimpinan kepala sekolah, Tinjauan Teoritik dan Permasalahannya. Jakarta: PT Raja Grafindo Persada

Wardiman Djojonegoro. (1998). Pengembangan sumber daya manusia melalui SMK, Jayakarta Agung Offset, Jakarta

Yamin, Martinis. (2008). Profesionalisasi guru dan implementasi KTSP. Jakarta: Gaung Persada Press 